\title{
Linking Innovation to Firm Performance in Developing Countries: the Role of Trade Liberalization
}

\author{
Benjamin Azembila Asunka ${ }^{1,2}$, Zhiqiang $\mathrm{Ma}^{1 *}$, Mingxing $\mathrm{Li}^{1}$, Oswin Aganda Anaba ${ }^{1,3}$
}

\begin{abstract}
This study set out to analyze the effect of innovation on firm performance in developing economies in the era of trade liberalization. The study uses data from the enterprise survey of the World Bank covering 19 Sub Saharan African countries surveyed between 2014 and 2016, with a total of 8,551 firms included. In order to effectively analyze the effect of innovation on firm performance, the CDM model is adopted to analyze $R \& D$ intensity, the effect of domestic $R \& D$ on innovation output, and the contribution of innovation to firm performance in the sub region. The study further tests for the effect of foreign technology and the import of products and services on the innovation process. Analysis is done using ordinary least squares. Findings suggest a positive and significant effect of foreign technology on domestic R\&D, while imports have a negative effect on domestic $R \& D$. Domestic $R \& D$ has positive effect on both product and process innovations among firms in the sub region. Moreover, both product and process innovations have a positive and significant effect on firm performance in the sub region. Meanwhile, the export of innovations is not found to be significant in this study. We therefore recommend that governments in the region should give tax incentives to organizations that import products that are meant specifically for the production of new products and processes. Firms in the sub region should also focus on narrow market segments where they have specialist expertise in, so as to be competitive in the global market.
\end{abstract}

Index Terms - product innovation; process innovation; firm performance; trade liberalization; CDM model; sub Saharan Africa

\section{INTRODUCTION}

Innovation is no longer just for creating value to benefit individuals, organizations, or societies but an activity that should create a smart future where people can enjoy the best quality of life [1]. To survive and enhance the quality of life, continuous innovation efforts have been identified as a spring board to propel national development, and hence improve livelihoods. All major revolutionary waves of human history - agricultural, industrial, information, and now convergence - are all about innovation for creating new and better value [2]. Innovation has thus taken center stage as the main driver of economic growth. The growth of developing countries is a result of ideas, and the organization of society and firms [3]. Innovation has been the backbone of important infrastructure such as electricity, ICT, and manufacturing systems that have transformed such economies. These innovation efforts have resulted in increase in total factor productivity, social changes and the improvement of the economic welfare of countries. Fagerberg, Srholec and Verspagen [3] identified two factors

Published on June 05, 2020.

${ }^{1}$ School of Management, Jiangsu University, China.

${ }^{2}$ School of Business and Management Studies, Bolgatanga Polytechnic, Bolgatanga, Ghana. that are crucial to the endogenous growth of economies; these are the adoption of technologies from outside the country and indigenous development of new technologies.

The purpose of this study is assess how innovation affects firm performance in Sub Saharan Africa (SSA) in the era of trade liberalization. Trade liberalization brings foreign competition into the domestic market, while opening up opportunities for local producers to export to counterpart countries. Indeed, the Economic Freedom of the World report (2004) asserts that economies with liberalized trade policies grow faster than those with protectionist policies [4]. International trade in the form of imports has also been strongly linked to innovation. Extant literature shows that imports into developing countries create 'escapecompetition' that leads to innovation by domestic firms [5][6] [7]. Studies have shown that in the aftermath of trade liberalization, innovation has been on the increase with foreign goods flooding local markets. This is evident in most studies done in Latin America[8][9][10]. Competition from imported products seems to have spurred innovation more in large firms [10] and in technologically advanced firms as opposed to small enterprises which constitute the large proportion of businesses in developing economies [9]. Medina [11] argues that import competition could bring about product upgrading opportunities, and local firms will react to changing preference by leveraging existing factors to produce new products [12].

Many scholars have explored the relationship between innovation and firm growth and concluded a positive relationship between the two variables [13][14][15]. Economies that have been popularly studied on this subject include transition economies [16][17][18], developed economies [19], and developing economies [20][21]. However, literature on this subject in the context of Sub Saharan Africa is still scant. Related areas explored in recent times in the sub region include the moderating role of institutional environment on innovation output in East Africa [22], the impact of operations as an informal firm on a firm's innovation decisions in Kenya [23]. Mlozi, Pesamaa \& Jack [24] examined the mediating role of innovation in the relationship between reciprocity and firm performance in South-Sudan and Tanzania, while Robson, Haugh, \& Obeng [25] analyzed the relationship between entrepreneurship and innovation in Ghana. Additionally, Abdu \& Jibir [26] assessed the major determinants of innovation in Nigeria. Ndemezo \& Kayitana [27] looked at the impact of innovation performance on financial performance of manufacturing

${ }^{3}$ Department of Liberal Studies, Bolgatanga Polytechnic, Bolgatanga, Ghana *Corresponding Author: mzhiqiang@yahoo.com 
firms in Rwanda, and Goedhuys [20] examined the relationship between firm learning and innovation in Tanzania.

This study extends existing literature on this subject by making the following contributions: (i) it analyzes the effect of innovation on firm performance in the context of Sub Saharan Africa. (ii) It considers the role played by international trade by testing the moderating roles of imports and foreign technology in the innovation process. Finally, the study adopts and extends the CDM model to include the role played by trade liberalization in the innovation efforts of firms in the sub region.

The rest of the study is organized as follows: Section 2 contains the background and concept of the study, section 3 is a review of related literature, sections 4 and 5 deal with the methodology of the study and discussion of results effectively. Finally section 6 contains the conclusions and policy ideas recommended following the study.

\section{BACKGROUND AND CONCEPT OF THE STUDY}

Trade liberalization brings foreign competition into the domestic market, while opening up opportunities for local producers to export to counterpart countries. Economies with liberalized trade policies grow faster than those with protectionist policies [4]. The World Bank reported that by 2015, annual global growth would be greater than it would be without trade liberalization (Global Economic Prospects 2004). The report also suggested that businesses in developing countries stand to gain if trade liberalization policies are implemented. Meanwhile, critics of trade liberalization opine that poor countries should be protected from competition and subjected to special rules. Contrary to this protectionism notion, more open countries in sub Saharan Africa such as Botswana and Mauritius have experienced rapid economic growth in recent times. Though it is noted that developing countries will gain more economic growth under trade liberalization, those in regions such as Latin America and the Caribbean are expected to gain more [28].

The growth of businesses has been linked to national economic development of countries both developed and developing ones. Developing economies in a quest to catch up with developed economies need to adopt a culture of innovation in order to spur economic development. China, India and Brazil which are largely recognized as emerging economies have successfully adopted and developed new technologies that have propelled economic growth [29][30] (Athreye \& Cantwell, 2007; Buckley \& Hashai, 2014; You \& Sarantis, 2013). However, the absorption and use of technology in developing countries is very expensive and will require a lot of efforts at national level to achieve [32]. Keller [32] further argues that it requires substantial human and financial resources in order to develop an abortive capacity necessary to achieve this, while Fu \& Gong [33] point out competent institutions and appropriate policies as a panacea to facilitate the process.

With most developing countries exporting mainly raw materials, efforts towards innovation could ensure value addition to these raw materials and spur economic growth. In a quest to bridge the technology gap between developing and the developed countries [34], the need to innovate has become more imperative. This catching-up process will mean investors in such countries have to learn a lot from those with leading technologies. The World Bank Report (2016) considers the bridging of the technological gap as one of the current economic challenges facing the world. However, the risk associated with investing in developing countries is often considered as very high [35]. Meanwhile within this uncertainty lies a great potential for rapid business growth through innovation.

The results of trade liberalization have been mixed, economic growth has been hard hit in several developing economies resulting in trade deficits. This is due largely to increased imports and less exports by many countries [36]. The World Bank and some donor agencies persuaded policy makers to believe that restrictions in trade are not the best option to protect local producers [37]. Hence developing countries opened up to several trade partners from developed countries. These arrangements bring severe competition from imported products, and put pressure on local producers to meet standards demanded by consumers in other countries.

At the center of the innovation drive is $R \& D$ investments which is well acclaimed to be a key input in the process. Several scholars including [38][39][40] found that R\&D has a positive effect on the generation of new knowledge. The effectiveness of firm level R\&D is influenced by such factors as firm size, industry, firm age and human capital. Moreover, for a country to get any benefits from knowledge spillover and boost its R\&D efforts, the absorptive capacity of such country needs to be developed. Absorptive capacity is linked to the level of skills of the workforce of a country. Skilled workforce has been noted to be an important factor for innovation. Fernandes \& Bank [41] posit that countries that are technologically endowed can catch up by absorbing advanced technologies from elsewhere [42]. Taking up technologies from foreign countries is a major contribution to product innovation in many firms. Successful innovation largely depends on the adoption and use of new and external knowledge vital to the process of innovation.

Based on the issues noted above, we conceptualize this study using the number of firms that invest in R\&D as R\&D intensity, while new products and processes introduced are proxy for innovation output. Imports and foreign technologies are hypothesized to be major influencers of the relationship between R\&D intensity and innovation output, and the export of innovations is also expected to be a major contributor to firm growth.

\section{RELATED LITERATURE}

\section{A. $R \& D$ and innovation output}

Innovation output is the end result of the efforts put in to generate new product or service ideas to meet the needs of the targeted buyers. Innovation output comes in the form of product, service, process, marketing or organizational work arrangement that is significantly improved and gives more value to the customer. This subject has generated interest among several scholars over the last decade who have analyzed relationship between innovation input and innovation output [30]. Different innovation activities have been found have a positive impact on the propensity to innovate and actual innovation. Extant literature on the innovation input-output nexus has mainly concentrated on 
$\mathrm{R} \& \mathrm{D}$ as the main input variable, and patent as the output variable. $R \& D$ is noted to be the leading factor of product innovation, whereas the acquisition of machinery leads mainly to process innovation [43]. In area of service provision, the quality of innovation is more difficult to measure. While in some cases the quality of the process is measured by timeliness of the process, others prefer to use the quality of process outputs such as customer satisfaction, accuracy etc. Process innovation mainly involves the improvement in the quality of service delivered and not based only the reduction of costs [44]. Several other factors have been linked to the rate and quality of innovation output, including both internal and external factors. R\&D investments, technology acquisition and the absorptive capacity of the firm are often mentioned as critical innovation inputs that lead to effective innovation output.

\section{$B$. International trade and innovation}

Much of extant literature posits that the use of imported inputs increases firm- productivity [45][46][46]. Import competition is found to have mixed effects on innovation, while imported intermediates generally have positive effects [5][7]. Firms that export from developing countries are under pressure to deliver high quality to their customers, this demand makes the firms import their inputs so that they can meet the level of quality needed [47]. Bas [48] posits that this arrangement is termed as direct imports, and does have a positive impact on innovation at firm level just as indirect imports do, a view supported by [49] and [46]. The import of these inputs further puts pressure on local producers of such inputs as they have to contend with imported products in the domestic market. Fieler, Eslava, \& Xu [50] argue that imported inputs can raise productivity of firms in developing countries which will lower production cost and allow them more access to international markets.

Gohchar \& Kuznetsov [51] find that firms that import intermediate goods and equipment are better positioned to increase innovation output. This capacity increase is based on the learning effects that come with the import of such products. Imports are a source of knowledge spillovers, while reliance on domestic inputs result in significant losses for economies that depend on high technology products from other countries. Yu, Li, Wang, \& Duan [52] find no significant effect of imported technology on innovation output. While some scholars find that import competition leads to an increase in R\&D intensity [53], others argue that there exists no clear relationship between import completion and productivity growth [54].

Moreover, exporting to other countries has been identified as a major boost for innovation and firm performance. In a quest to take advantage of opportunities that exist elsewhere, businesses need to design products that can satisfy such needs, hence the need for novel ideas. The main arguments advanced for this idea is that firms learn by exporting to other countries due to new challenges and opportunities [12][53] argue that technologically advanced firms usually respond to export opportunities by innovating to meet the expectations of the international target market, a view that is largely referred to as 'learning-by-exporting'. Developing countries can benefit from this learning when they export to more develop economies where there is scope and opportunities for marketing more products. Having access to international markets due to trade liberalization is found to have an impact on firms' decision to employ modern technology to the quality of products [55]. It also means increasing R\&D expenditure and engaging in more innovation efforts [56]. This liberalization arrangement also enables access to critical intermediate inputs, which enhances the diffusion of new knowledge aids the R\&D process [57], and lead to an upgrade of the quality of products [50][58].

\section{Technology and innovation process}

The adoption and use of technology is a vital factor in the innovation process. Fartash et al. [15] argue that Technology acquisition and use has a significant and positive effect on both firm innovation and firm performance. ICT is effective in enhancing production efficiency and in generating interindustry spillovers [59]. Technology can be more effective when technical know-how is combined with knowledge from other sources in the innovation process [60]. Convergence of science, technology, markets, and industries give rise to further product and market development. Such convergence prerequisite for conceiving and churning out new innovations [61]. Venturini [62]posits that both ICT and R\&D have positive but independent effects on Total Factor Productivity (TFP), while [63] emphasize that there is a relationship between ICT, R\&D and other activities geared towards innovation.

Developing countries are increasingly adopting technologies from advanced economies [64], and these technologies can serve as important inputs in the innovation process. These inputs become more available as more foreign firms find grounds for such, thereby reducing costs associated with novel technologies that aid the innovation process [65]. Edwards, Sanfilippo, \& Sundaran [66] also found that increasing exports increases the importation of inputs from advanced economies. Some studies have found that import competition has mixed effects on innovation, while imported intermediates generally have positive effects [5][7]. Firms that export from developing countries are under pressure to deliver high quality to their customers, this demand makes the firms import their inputs so that they can meet the level of quality needed [47]. Bas [48]posits that this arrangement is termed as direct imports, and does have a positive impact on innovation at firm level just as indirect imports do, a view supported by [49][67][68]. The import of these inputs further puts pressure on local producers of such inputs as they have to contend with imported products in the domestic market.

\section{MATERIALS AND METHODS}

A. Data

The data for this study is firm level data captured by the enterprise survey of the World Bank. The report contains economic data on 135,000 firms in 139 countries. For the purpose of this study we take firm level data of 19 Sub Saharan African countries surveyed between 2014 and 2016, with a total of 8,551 firms. The sample is based on data availability, countries involved in this sample are all developing countries that are trying to catch up with the developed world in the area of innovation. Meanwhile, in an era of trade liberalization, firms in these countries have to compete with imported products from other countries, and 
also have the opportunity to export products. Variables for this study are explained in Table 1.

TABLE I: Variables for the study.

\begin{tabular}{|c|c|}
\hline Variable & Description \\
\hline$R \& D$ & $\begin{array}{l}\text { Number of firms that invest in research and } \\
\text { development }\end{array}$ \\
\hline $\begin{array}{r}\text { Product } \\
\text { innovation } \\
(\text { PdtInn })\end{array}$ & New products introduced within the period \\
\hline $\begin{array}{l}\text { Process innovation } \\
(\text { PrcInn })\end{array}$ & New processes introduced within the period \\
\hline Import & hat have imported products \\
\hline Export & hat exported products \\
\hline $\begin{array}{l}\text { Foreign } \\
\text { technology }(\boldsymbol{F T})\end{array}$ & $\begin{array}{l}\text { Number of firms that used foreign technology in their } \\
\text { operations }\end{array}$ \\
\hline $\begin{array}{l}\text { Access to finance } \\
\text { (AccFin) }\end{array}$ & $\begin{array}{l}\text { Number of firms that have access to external } \\
\text { financing }\end{array}$ \\
\hline Email & Number of firms that have official email addresses \\
\hline Website & Number of firms that have websites \\
\hline $\begin{array}{l}\text { Public } \\
\text { (Pubfirm) }\end{array}$ & Number of firms that are state owned \\
\hline $\begin{array}{l}\text { Private firms } \\
(\text { Prfirm })\end{array}$ & Number of firms that are owned by private investors \\
\hline $\begin{array}{l}\text { Foreign firms } \\
\text { (Forfirm) }\end{array}$ & $\begin{array}{l}\text { Number of firms that are owned by foreign } \\
\text { investors }\end{array}$ \\
\hline $\begin{array}{l}\text { Skilled workers } \\
(\text { Skw })\end{array}$ & $\begin{array}{l}\text { Number of employees with requisite skills for the } \\
\text { job }\end{array}$ \\
\hline $\begin{array}{l}\text { Firm performance } \\
(\text { Perf })\end{array}$ & $\begin{array}{l}\text { Annual increase in sales by firms (percentage } \\
\text { increase) }\end{array}$ \\
\hline
\end{tabular}

TABLE II: Descriptive statistics

\begin{tabular}{lllrrl}
\hline Variable & Obs. & Mean & Std. dev. & Min & Max \\
\hline R\&D & 19 & 91.36 & 97.79 & 3 & 369 \\
\hline $\begin{array}{l}\text { Product } \\
\text { innovation }\end{array}$ & 19 & 255.31 & 316.95 & 12 & 1410 \\
\hline $\begin{array}{l}\text { Process } \\
\text { innovation }\end{array}$ & 19 & 261.73 & 381.86 & 7 & 1683 \\
\hline Imports & 19 & 204.63 & 314.07 & 17 & 853 \\
\hline Exports & 19 & 78.05 & 111.06 & 18 & 522 \\
\hline $\begin{array}{l}\text { Foreign } \\
\text { technology }\end{array}$ & 19 & 76.26 & 66.51 & 3 & 271 \\
\hline $\begin{array}{l}\text { Access to } \\
\text { finance }\end{array}$ & 19 & 83.37 & 58.88 & 18 & 191 \\
\hline E-mail & 19 & 249.78 & 178.60 & 40 & 629 \\
\hline Website & 19 & 139.73 & 137.88 & 18 & 597 \\
\hline Private firms & 19 & 429.21 & 445.43 & 46 & 1981 \\
\hline Public firms & 19 & 20.84 & 48.36 & 1 & 214 \\
\hline Foreign firms & 19 & 93.37 & 104.40 & 6 & 374 \\
\hline Skilled workers & 19 & 418.36 & 464.26 & 50 & 2121 \\
\hline $\begin{array}{l}\text { Firm } \\
\text { performance }\end{array}$ & 19 & 10.84 & 11.13 & 2 & 44 \\
\hline
\end{tabular}

\section{B. Econometric model}

One of the most appropriate models for measuring innovation and performance is the CDM model [69]. It employs the Cobb-Douglas production function to incorporate the element of knowledge and connect R\&D activity to innovation and firm performance. Many scholars have found this model useful for measuring innovation and firm performance, it has been used to analyze micro data of over 40 countries [70]. The model is commonly used due to its ability to overcome some difficulties encountered in measuring innovation and productivity. One major problem is simultaneity which arises because firms differ in factors they consider important in their decision to innovate, and their levels of expenditure and the performance of new product ideas. The classical CDM model contains four stages, the first and second steps seek to describe the innovation efforts of an entity.

The third step analyses the level of innovation output, and the fourth step describes the performance of the novel idea. The model is generic model is specified as follows:

The first stage represents the decision of the firms to undertake the

$\mathrm{R} \& \mathrm{D}$ investments:

$\gamma_{i}=x_{1 i} \beta_{1}+u_{1 i}$

Where $\gamma_{i}$ expresses the decision to invest in R\&D, $x_{1 i}$ represent explanatory variables, $\beta_{1}$ is the coefficient of explanatory variables; and $u_{1 i}$ the error term.

The second stage is the R\&D equation which determines the intensity of the R\&D:

$$
k_{i}=x_{2 i} \beta_{2 i}+u_{2 i}
$$

where: $k_{i}$ is R\&D investments of firm $i ; x_{2 i}$ is a vector of explanatory variables; $\beta_{2}$ is the coefficient of explanatory variables; and $u_{2 i}$ the error term.

In principle, the explanatory variables $x_{1}$ and $x_{2}$ are the same

The third stage measures the innovation output of the firm from the R\&D investment. Hence:

$$
I_{i}=k_{i}+x_{3 i} \beta_{3 i}+u_{3 i}
$$

where: $I_{i}$ is the innovation output; $k_{i}$ is the R\&D variable; $x_{3 i}$ represents explanatory variables, and $u_{3 i}$ is the error term.

The fourth stage is performance, it measures the effect of the innovation output on the performance of the firm.

The estimated performance equation is:

$P_{i}=I_{i}+x_{4 i} \beta_{4}+u_{4 i}$

where: $P_{i}$ is the performance variable; $x_{4 i}$ represents explanatory factors of performance, and $u_{4 i}$ is the error term.

\section{The extended CDM model}

We estimate our model in three stages. As noted earlier, the explanatory variables for the first and second stages are the same, hence we estimate R\&D intensity as the first step. The second and third stages are the innovation output and firm performance respectively.

\section{$R \& D$ investments}

Many researchers have written a lot about the relationship between R\&D and innovation [26][71][72]. They emphasize that R\&D plays a major role in boosting innovation and hence productivity. At the center of the innovation drive is $R \& D$ investments which is well acclaimed to be a key input in the process. Several scholars including [38][39][73] found that R\&D has a positive effect on the generation of new knowledge. International trade brings foreign technology close to firms in developing countries. The absorptive capacity of firms enables them to adopt and use these technologies effectively [74]. Therefore, we consider skilled workers as important in the R\&D activity as it is directly linked to absorptive capacity. While the above factors are used as the main explanatory variables, a variable $X$ is included in the equation as a vector of control variables, including foreign interest, state interest, access to finance, email and website.

As stated earlier, the explanatory variables for the first and second stages are essentially the same, therefore we construct one equation to study the function of R\&D intensity for firms in the sub-region to represent the first two stages (Masso and 
Vahter, 2014; Yuan \& Xiang, 2018). Hence,

\section{Model 1}

$$
R \& D_{i}=a+\beta_{1} I M P_{i}+\beta_{2} F T_{i}+\beta_{4} S K W_{i}+\beta_{5} X_{i}+u_{i}
$$

\section{Innovation estimation}

This stage estimates the innovation output resulting from the investments in R\&D. Technology is considered a key factor in this phase of innovation. Fartash et al. [15] posit that technology acquisition and use has a significant positive effect on both firm innovation and firm performance. The adoption and use of such technologies enhances production efficiency and in generating inter-industry spillovers [59]. However, technology can be more effective when technical know-how is combined with knowledge from other sources in the innovation process [77]. Venturini [62]opines that both ICT and R\&D have positive but independent effects on Total Factor Productivity (TFP), while Corrado et al. [63] emphasize that there is a relationship between ICT, R\&D and other activities geared towards innovation. Trade liberalization presents opportunities for firms in developing countries to access new technologies that can aid the innovation process. New technologies are effective when domestic firms have the capability to acquire and use them.

We estimate innovation at this stage on two levels; (i) product innovation and (ii) process innovation. In models 2 and 3 we consider R\&D, foreign technology, imports, FDI, staff training and skilled workers as the main explanatory variables. In models 4 and 5 we consider the effect of complementarities between R\&D and foreign technology, R\&D and imports, and R\&D and FDI on innovation output. This will further our understanding of influence of international trade arrangements on innovation in the sub region. A vector of control variables denoted by $\mathrm{X}$ are same as those in model 1.

Model 2

$$
\begin{aligned}
& \operatorname{PdtInn}_{i}=a+\beta_{1} R \& D_{i}+\beta_{2} I M P_{i}+\beta_{3} S T T_{i}+ \\
& \beta_{4} S_{i} W_{i}+\beta_{5} X_{i}+u_{i} \\
& \quad \text { Model } 3 \\
& P d t I n n_{i}=a+\delta_{1} R \& D_{i}+\delta_{2}(R \& D \times F T)_{i}+\delta_{3}(R \& D \times \\
& I M P)_{i}+\delta_{4} X_{i}++u_{i} \\
& \quad \text { Model } 4 \\
& \quad \operatorname{PrCInn}_{i}=a+\vartheta_{1} R \& D_{i}+\vartheta_{2} I M P_{i}+\vartheta_{3} F D I_{i}+ \\
& \vartheta_{4} E M P T_{i}+\vartheta_{5} X_{i}+u_{i} \\
& \text { Model } 5 \\
& \operatorname{PrCInn}_{i}=a+\delta_{1} R \& D_{i}+\delta_{2}(R \& D \times F T)_{i}+\delta_{3}(R \& D \times \\
& F D I)_{i}+\delta_{4} X_{i}+u_{i}
\end{aligned}
$$

\section{Performance estimation}

Performance is measured in this study as the effect of both product and process innovation on sales generated by the firm. Skilled workers has been noted to be an important source of competitive advantage for innovation and firm performance (Fernandes \& Paunov, 2013). In order to develop such capacity, employee training has been constantly emphasized as important activity in innovation efforts [6].

Model 6

$\operatorname{Perf}_{i}=a+\varphi_{1} \operatorname{PdtInn}_{i}+\varphi_{2} \operatorname{PrCInn}_{i}+\varphi_{3} E M P T_{i}+$ $\varphi_{4} S K W_{i}+\varphi_{5} X_{i t}+\varepsilon_{i t}$

\section{RESULTS AND DISCUSSION}

This section presents the analysis and interpretation of data using Ordinary Least Squares (OLS). Variables are analyzed in their natural logarithm form, hence results can be interpreted as elasticities.

\section{A. Regression analysis}

The regression analysis of models and results of the multistage model are indicated in Table 3.

\section{B. Discussion of results}

\section{$R \& D$ intensity}

This stage seeks to test for level of R\&D activity among firms and the potential influence of foreign technology and import of other products. Evidence from the results in Table 3 shows a positive and significant effect of foreign technology on domestic R\&D, with the potential to increase R\&D intensity by $3.8 \%$ per a percentage increase in foreign technology in the R\&D process. However, a percentage increase in the import of products and services can reduce domestic R\&D intensity by $6.2 \%$. Domestic firms in the sub region can boost their $R \& D$ activities with the use of foreign technology as inputs. Following this, product and process innovation are boosted by $R \& D$, but negatively impacted by imports. Foreign technology shows no significant effect on both product and process innovation in this study.

The revelations in this study support previous studies [78][79] that found significant complementarities between R\&D and foreign of foreign technology. Though imports in general stifle R\&D and innovation output, the combination with internal R\&D proves to be very effective in boosting innovation activities. The technical efficiency of African countries is found in this study to be negatively impacted by imports. Biggs [80]attributes this effect to the lack of organized R\&D activities in the sub region. The adoption of technology from other countries is conditioned on the absorptive capacity of the receiving country. Developing countries however, lack this absorptive capacity due to lack of skilled human resources to adopt and successfully use new technologies [79]. The results further demonstrate that spending on R\&D activities is the most consistent factor that positively affects product and process innovations. This is in line with several studies including those pointed out above. In the sub region $R \& D$ is one of most relevant factors explaining firm level innovation. This phenomenon could be based on the fact that firms often rely on their own R\&D in churning out product and process innovations since resources in the domestic markets are scarce.

TABLE III: Regression Analysis of Models 


\begin{tabular}{|c|c|c|c|c|c|c|}
\hline & $\begin{array}{c}\text { Model } \\
1\end{array}$ & $\begin{array}{c}\text { Model } \\
2\end{array}$ & $\begin{array}{c}\text { Model } \\
3\end{array}$ & $\begin{array}{c}\text { Model } \\
4\end{array}$ & $\begin{array}{c}\text { Model } \\
5\end{array}$ & Model 6 \\
\hline & $R \& D$ & PdtInn & PrcInn & PdtInn & & Perf \\
\hline$R \& D$ & & $\begin{array}{l}0.062 * \\
* * \\
(0.010)\end{array}$ & $\begin{array}{l}0.054 * \\
* \\
(0.017)\end{array}$ & & & \\
\hline $\operatorname{Imp}$ & $\begin{array}{l}-0.062^{*} \\
(0.066)\end{array}$ & $\begin{array}{l}- \\
0.073 * \\
* \\
(0.037)\end{array}$ & $\begin{array}{l}- \\
0.042 * \\
* \\
(0.019)\end{array}$ & & & \\
\hline$F T$ & $\begin{array}{l}0.038^{* * *} \\
(0.014)\end{array}$ & $\begin{array}{l}0.436 \\
(0.567) \\
\end{array}$ & $\begin{array}{l}0.332 \\
(0.309)\end{array}$ & & & \\
\hline Skw & $\begin{array}{l}-0.337 * * * \\
(0.161)\end{array}$ & $\begin{array}{l}- \\
0.216^{*} \\
* \\
(0.084)\end{array}$ & $\begin{array}{l}- \\
1.122 * \\
* * \\
(0.384)\end{array}$ & & & $\begin{array}{l}0.021 \\
(0.043)\end{array}$ \\
\hline Website & $\begin{array}{l}-0.014 \\
(0.166)\end{array}$ & & & & & $\begin{array}{l}0.106^{* *} \\
(0.030)\end{array}$ \\
\hline Prfirm & $\begin{array}{l}0.065^{* * *} \\
(0.008)\end{array}$ & $\begin{array}{l}0.076^{*} \\
* * \\
(0.005)\end{array}$ & $\begin{array}{l}0.063 * \\
* * \\
(0.004)\end{array}$ & $\begin{array}{l}0.707^{*} \\
* \\
(0.299)\end{array}$ & $\begin{array}{l}0.087^{*} \\
* \\
(0.016)\end{array}$ & $\begin{array}{l}0.275^{* *} \\
(0.129)\end{array}$ \\
\hline Forfirm & $\begin{array}{l}0.385^{* * *} \\
(0.114)\end{array}$ & $\begin{array}{l}0.375^{*} \\
* * \\
(0.052)\end{array}$ & $\begin{array}{l}0.043 * \\
* * \\
(0.008)\end{array}$ & $\begin{array}{l}0.332 * \\
* \\
(0.062)\end{array}$ & $\begin{array}{l}0.575^{*} \\
* \\
(0.259)\end{array}$ & $\begin{array}{l}0.035^{* *} \\
(0.017)\end{array}$ \\
\hline Pubfirm & $\begin{array}{l}0.040 \\
(0.152) \\
\end{array}$ & $\begin{array}{l}0.025 \\
(0.575) \\
\end{array}$ & $\begin{array}{l}0.089^{*} \\
(0.006)\end{array}$ & $\begin{array}{l}0.268 \\
(0.521)\end{array}$ & $\begin{array}{l}0.363 \\
(0.388) \\
\end{array}$ & $\begin{array}{l}0.226^{*} \\
(0.101) \\
\end{array}$ \\
\hline Email & $\begin{array}{l}0.325 * * * \\
(0.057)\end{array}$ & & & & & $\begin{array}{l}0.054^{* *} \\
(0.017)\end{array}$ \\
\hline Accfin & $\begin{array}{l}0.331^{*} \\
(0.181)\end{array}$ & $\begin{array}{l}0.897 * \\
* \\
(0.052)\end{array}$ & $\begin{array}{l}0.354 * \\
* * \\
(0.040)\end{array}$ & $\begin{array}{l}0.504 * \\
* * \\
(0.083)\end{array}$ & $\begin{array}{l}0.895^{*} \\
* \\
(0.344)\end{array}$ & \\
\hline$R \& D \times F T$ & & & & $\begin{array}{l}0.042 * \\
* * \\
(0.025)\end{array}$ & $\begin{array}{l}0.057^{*} \\
* \\
(0.002)\end{array}$ & \\
\hline $\begin{array}{l}R \& D \\
\times I m p\end{array}$ & & & & $\begin{array}{l}0.151^{*} \\
* * \\
(0.002)\end{array}$ & $\begin{array}{l}0.033 \\
(0.050)\end{array}$ & \\
\hline PrcInn & & & & & & $\begin{array}{l}0.079 * * \\
* \\
0.015\end{array}$ \\
\hline
\end{tabular}

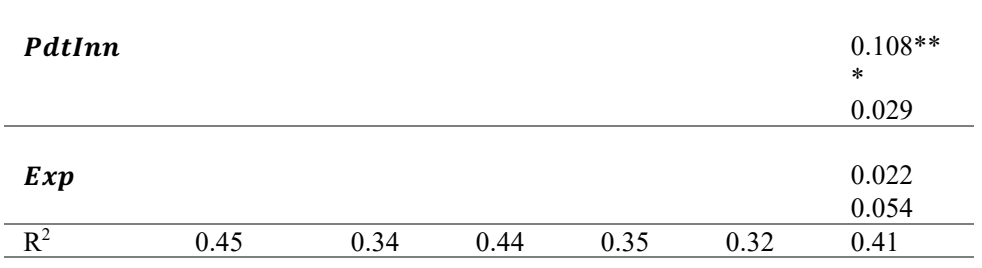

$\operatorname{Prob}(\mathrm{Rn}-$

$\begin{array}{lllllll}\text { squared stat.) } & 0.000 & 0.000 & 0.000 & 0.000 & 0.000 & 0.000\end{array}$

Note: Standard errors are in parentheses, significance levels are denoted by $* * *, * *$, and * respectively

\section{Effects on innovation output}

Research and development (R\&D) is found to have a positive and significant effect on product and process innovations. A percentage increase in R\&D intensity leads to $6.2 \%$ and $5.4 \%$ increase in product and process innovations effectively. Imports are found to have a negative and significant impact on both product and process innovation among firms in the sub region. The complementarity between $R \& D$ and foreign technology also shows a positive effect on innovation output, demonstrating that foreign technology imported purposely for product and process innovation boosts innovation efforts among firms. However, an increase in the import of general products and services leads to a decrease in innovation output. Every percentage increase in such imports leads to $7.3 \%$ and $4.2 \%$ decrease in product and process innovations effectively. This negative effect has been reported by other scholars on developing economies [81][82]. Contrary to these findings, some scholars have found that imports actually have a positive and significant effect on innovation output [83][6][84]. They argue that the import of intermediate inputs enhance new product innovation since such resources and technologies are not available in the domestic market. In the SSA particularly, some studies have reported mixed findings on the effect of imports on new product innovation. One such study by Abubakar, Hand, Smallbone, \& Saridakis [85] found no significant effect of imports on new product innovation in the SSA. They argue that this could be as a result of these countries importing from other developing countries instead of developed whose imports are proven to have a significant impact on new product innovation.

The complementarity between R\&D and imports, $\mathrm{R} \& \mathrm{D}$ and foreign technology has significant and positive effect on innovation output. However, the insignificant effect of foreign technology on innovation output in this study could be due to inability of staff adopt and use such technologies effectively. Thutupalli \& Iizuka [34] argue that the adoption and use of foreign technology is an important factor of innovation, but adoption of such technology is dependent on the capacity of firms to absorb them successfully. Investments in R\&D and foreign technology do not in themselves yield efficiency gains unless it is effectively used in the innovation process [33]. Foreign technology plays a pivotal role when employed in the R\&D process leading to new product innovation. Lee \& Malerba [86]opine that some developing countries still lack indigenous technologies, they rely mostly on technology from advanced economies [3]. Trade liberalization plays a significant in this regard by affording developing countries the opportunity to access foreign technology and technical knowhow [87]. On the flip side, trade liberalization brings with it increasing competition in the domestic market, which poses a threat to the existence and growth of small enterprises in the sub region. Hence innovation in such firms will suffer setbacks since potential local buyers will prefer foreign technologies as inputs as such technologies will continue to be ahead of those in developing economies.

\section{Effect on firm performance}

In line with findings by many authors, this study finds that both product and process innovations have positive and significant effect on firm performance. Process innovation increases firm performance by $7.9 \%$, while product innovation leads to a $10.8 \%$ increase in firm performance for every percentage increase in innovation output. Though new product failure is a common phenomenon [88], the new products that eventually become successful contribute enormously to the growth of firms. Innovation in both forms has a positive and significant effect on firm performance. Product innovation shows more significant effect on firm productivity than process innovation in the sub region. The export of innovations from the sub region however, shows no significant effect on frim performance, probably because domestic firms are not able to take advantage of opportunities that exist in international markets. The critical role played by innovation in the success of firms is manifest in the performance of private and foreign firms as opposed to public 
firms. The relatively low performance in the public sector could be due to the low levels innovation among owned by the governments of various countries. The ownership of website still poses a negative effect on firm performance, while an official email shows positive effect on firm performance.

Some studies have concluded that developed economies learn from international customers through exports [89], but for the SSA, exporting does not show a significant effect on firm growth. This could be as a result of a relatively small amount of products being exported from the sub region. There is a replicating effect from $R \& D$ since it is aided by foreign technology, making products from the sub region less competitive to those from the developed world. Besides most firms in the SSA are small and fragmented businesses that lack the capacity to produce the required quality and quantity demanded by customers abroad. Almodovar, Saiz-Briones, \& Silverman [90]posit that exporting increases a firm's access to more technical knowhow and leads to better innovation and productivity. For firms in the SSA however, the opportunity to learn from foreign markets and grow still remains very limited since not much is done in terms of exporting.

\section{CONCLUSION AND POLICY IDEAS}

The aim of this study is to analyze the effect of innovation on firm performance in the context of developing countries, and the role that international trade plays in this process. Using Sub Saharan Africa as a study area, data from the enterprise survey of the World Bank is adopted for this analysis. The data covers 19 Sub Saharan African countries surveyed between 2014 and 2016, with a total of 8,551 firms included. The study then adopts the CDM model to do a multistage analysis of the innovation process; from R\&D investments, innovation output and innovation performance. The analysis resulted in the following conclusions.

First, this study reports a positive and significant effect of foreign technology on domestic R\&D. on the hand, imports are seen to impact on domestic R\&D negatively. Foreign technology meant purposely for R\&D activities in the sub region is a panacea for increased innovation activities. Second, domestic R\&D contribute significantly to both product and process innovations among firms in the sub region. The direct effect of foreign technology however does not show up significantly. The effect of foreign technology in the innovation process is felt through its contribution to domestic R\&D processes. Third, the import of products and services into the sub region generally stifle domestic innovation. However, as in the case of foreign technology, imports will benefit innovation among firms in the sub region if the imported products are meant for $R \& D$ processes that result in improved innovation activities. Fourth, both product and process innovations have a positive and significant effect on firm performance in the sub region. Increased innovation activities therefore are needed in order to expand business organizations in the region. Fifth, the effect of the export of innovations is not significant in this study. This could be due to the inability of firms in the sub region to compete effectively in the global market. Increased innovation activities will prove very useful in making these firms competitive internationally.

Following the above conclusions, effective policies that will help firms in the sub region to improve on their innovation efforts include the following. First, governments in the region should give tax incentives to organizations that import products that are meant specifically for the production of new products and processes. This will enable the domestic import equipment that will help add value to domestic raw materials for domestic and foreign markets. Second, firms in the sub region will be competitive in the global market if they focus on narrow segments of the market. Market segments that can be targeted for improved competitiveness are those that demand products that lie within areas where these countries have competitive advantage in terms of raw material supply or technical knowhow. Improved innovation and niche marketing will help improve firm performance and competitiveness in the sub region.

Conflict of Interest: The authors declare no conflict of interest in this work.

\section{ACKNOWLEDGMENT}

This work is supported by the Social Science Funding Project of Jiangsu Province (No. 18GLB024)

\section{REFERENCES}

[1] S. M. Lee and S. Trimi, "Innovation for creating a smart future," $J$. Innov. Knowl., vol. 3, no. 1, pp. 1-8, 2018.

[2] S. M. Lee, D. L. Olson, and S. Trimi, "Innovative collaboration for value creation,” Organ. Dyn., vol. 41, no. 1, pp. 7-12, 2012.

[3] J. Fagerberg, M. Srholec, and B. Verspagen, Innovation and economic development, 1st ed., vol. 2, no. 1. Elsevier B.V., 2010.

[4] J. Gwartney and R. Lawson, "Economic Freedom ofthe World: 2004 Annual Report." The Fraser Institute, Vancouver, 2004.

[5] Z. Xie and J. Li, "Exporting and innovating among emerging market firms: The moderating role of institutional development," J. Int. Bus. Stud., vol. 49, no. 2, pp. 222-245, 2018.

[6] K. Seenaiah and B. N. Rath, "Determinants of innovation in selected manufacturing firms in India: Role of R\&D and exports," Sci. Technol. Soc., vol. 23, no. 1, pp. 65-84, 2018.

[7] P. Shu and C. Steinwender, "The impact of trade liberalization on firm productivity and innovation," Innov. Policy Econ., vol. 19, no. 1, pp. 39-68, 2019.

[8] M. Bas and I. Ledezma, "Trade integration and within-plant productivity evolution in Chile," Rev. World Econ., vol. 146, no. 1, pp. 113-146, 2010 .

[9] L. Iacovone, "The better you are the stronger it makes you : Evidence on the asymmetric impact of liberalization th," J. Dev. Econ., vol. 99, no. 2, pp. 474-485, 2012.

[10] A. M. Fernandes and C. Paunov, "Does trade stimulate product quality upgrading?," Can. J. Econ. Can. d'économique, vol. 46, no. 4, pp. 1232-1264, 2013.

[11] P. Medina, "Import Competition, Quality Upgrading and Exporting: Evidence from the Peruvian Apparel Industry," Univ. Toronto Mimeo, pp. 1-79, 2017.

[12] N. Bloom, M. Draca, and J. Van Reenen, "Trade induced technical change? The impact of chinese imports on innovation, IT and productivity," Rev. Econ. Stud., vol. 83, no. 1, pp. 87-117, 2016.

[13] F. Crowley and P. McCann, "Firm innovation and productivity in Europe: evidence from innovation-driven and transition-driven economies," Appl. Econ., vol. 50, no. 11, pp. 1203-1221, 2018.

[14] A. Exposito and J. A. Sanchis-Llopis, "Innovation and business performance for Spanish SMEs: New evidence from a multidimensional approach," Int. Small Bus. J., vol. 36, no. 8, pp. 911-931, 2018.

[15] K. Fartash et al., "The Impact of Technology Acquisition \& Exploitation on Organizational Innovation and Organizational Performance in Knowledge-Intensive Organizations," Eurasia J. Math. Sci. Technol. Educ., vol. 14, no. 4, pp. 1497-1507, 2018.

[16] G. Berulava and T. Gogokhia, "Complementarities of Innovation Strategies: Evidence from Transition Economies," in Eurasian Economic Perspectives, Springer, 2018, pp. 169-192.

[17] V. Ramadani, R. D. Hisrich, H. Abazi-Alili, L.-P. Dana, L. Panthi, and L. Abazi-Bexheti, "Product innovation and firm performance in transition economies: A multi-stage estimation approach," Technol. 
Forecast. Soc. Change, vol. 140, pp. 271-280, 2019.

[18] A. T. Karabulut, "Effects of innovation types on performance of manufacturing firms in Turkey," Procedia-Social Behav. Sci., vol. 195, pp. 1355-1364, 2015.

[19] D. Isogawa, K. Nishikawa, and H. Ohashi, "New-to-Market Product Innovation and Firm Performance: Evidence from a firm-level innovation survey in Japan," Citeseer, 2012.

[20] M. Goedhuys, "Learning, product innovation, and firm heterogeneity in developing countries; Evidence from Tanzania," Ind. Corp. Chang., vol. 16, no. 2, pp. 269-292, 2007.

[21] J. Masso and P. Vahter, "The role of product-level dynamics in export growth and productivity: evidence from Estonia," Emerg. Mark. Financ. Trade, vol. 50, no. 4, pp. 42-60, 2014.

[22] L. Barasa, J. Knoben, P. Vermeulen, P. Kimuyu, and B. Kinyanjui, "Institutions, resources and innovation in East Africa: A firm level approach," Res. Policy, vol. 46, no. 1, pp. 280-291, 2017.

[23] P. Mendi and R. Mudida, "The effect on innovation of beginning informal: Empirical evidence from Kenya," Technol. Forecast. Soc. Change, vol. 131, no. June, pp. 326-335, 2018.

[24] S. Mlozi, O. Pesämaa, and S. Jack, "Role of reciprocity and innovativeness on performance in a developing context: Empirical evidence from Africa," African J. Sci. Technol. Innov. Dev., vol. 10, no. 1, pp. 69-84, 2018.

[25] P. J. A. Robson, H. M. Haugh, and B. A. Obeng, "Entrepreneurship and innovation in Ghana: Enterprising Africa," Small Bus. Econ., vol. 32, no. 3, pp. 331-350, 2009.

[26] M. Abdu and A. Jibir, "Determinants of firms innovation in Nigeria," Kasetsart J. Soc. Sci., vol. 39, no. 3, pp. 448-456, 2018.

[27] E. Ndemezo and C. Kayitana, "Innovation and Firms 'Performance in the Rwandese Manufacturing Industry . A firm Level Empirical Analysis," no. January, pp. 1-19, 2017.

[28] K. Anderson, W. Martin, and D. Van der Mensbrugghe, "Global impacts of the Doha Scenarios on poverty," WTO, p. 497, 2005.

[29] S. Athreye and J. Cantwell, "Creating competition?: Globalisation and the emergence of new technology producers," Res. Policy, vol. 36, no. 2, pp. 209-226, 2007.

[30] P. J. Buckley and N. Hashai, "The role of technological catch up and domestic market growth in the genesis of emerging country based multinationals," Res. Policy, vol. 43, no. 2, pp. 423-437, 2014.

[31] K. You and N. Sarantis, "Structural breaks, rural transformation and total factor productivity growth in China," J. Product. Anal., vol. 39, no. 3, pp. 231-242, 2013.

[32] W. Keller, "International technology diffusion," J. Econ. Lit., vol. 42 no. 3, pp. 752-782, 2004

[33] X. Fu and Y. Gong, "Indigenous and foreign innovation efforts and drivers of technological upgrading: evidence from China," World Dev., vol. 39, no. 7, pp. 1213-1225, 2011.

[34] A. Thutupalli and M. Iizuka, "Catching-up in agricultural innovation : the case of Bacillus thuringiensis cotton in India," pp. 1-18, 2016.

[35] Y. W. Cheung, J. De Haan, X. Qian, and S. Yu, "China's Outward Direct Investment in Africa," Rev. Int. Econ., vol. 20, no. 2, pp. 201220, 2012.

[36] C. Ackah and O. Morrissey, "Trade Policy and Performance in SubSaharan Africa since the 1980s," African Dev. Bank Econ. Res. Work. Pap., vol. 78, no. 05, 2005.

[37] D. Greenaway and O. Morrissey, "Multilateral institutions and unilateral trade liberalisation in developing countries," in Trade and Development, Springer, 1996, pp. 135-160.

[38] A. Musolesi and J.-P. Huiban, "Innovation and productivity in knowledge intensive business services," J. Product. Anal., vol. 34, no. 1, pp. 63-81, 2010.

[39] B. H. Hall, "Innovation and productivity in firms," no. March, pp. 1$11,2011$.

[40] G. Teplykh, "Analysis of the Innovation Activities of Firms Using the CDM Approach,” Probl. Econ. Transit., vol. 58, no. 5, pp. 443-462, 2016.

[41] A. M. Fernandes and W. Bank, "Does trade stimulate product quality upgrading ?," vol. 46, no. 4, 2013

[42] R. J. Barro and X. Sala-I-Martin, "Technological Diffusion, Convergence, and Growth," J. Econ. Growth, vol. 2, no. 1, pp. 1-26, 1997.

[43] L. Potters, "Innovation input and innovation output: differences among sectors," IPTS Working Papers on Corporate R\&D and Innovation, 2009

[44] H. Snyder, L. Witell, A. Gustafsson, P. Fombelle, and P. Kristensson, "Identifying categories of service innovation: A review and synthesis of the literature," vol. 69, no. 7, pp. 2401-2408, 2016.

[45] G. Gopinath and B. Neiman, "Trade adjustment and productivity in large crises," Am. Econ. Rev., vol. 104, no. 3, pp. 793-831, 2014.

[46] N. Foster-McGregor, A. Isaksson, and F. Kaulich, "Importing, exporting and performance in sub-Saharan African manufacturing firms," Rev. World Econ., vol. 150, no. 2, pp. 309-336, 2014.

[47] M. Bas and V. Strauss-Kahn, "Does importing more inputs raise exports? Firm-level evidence from France," Rev. World Econ., vol. 150, no. 2, pp. 241-275, 2014.

[48] M. Bas, "Input-trade liberalization and fi rm export decisions: Evidence from Argentina," J. Dev. Econ., vol. 97, no. 2, pp. 481-493, 2012.

[49] L. Halpern, M. Koren, and A. Szeidl, "Imported Inputs and Productivity $\dagger, "$ vol. 105, no. 12, pp. 3660-3703, 2015.

[50] A. C. Fieler, M. Eslava, and D. Y. Xu, "Trade, quality upgrading, and input linkages: Theory and evidence from Colombia," Am. Econ. Rev., vol. 108, no. 1, pp. 109-146, 2018.

[51] K. Gonchar and B. Kuznetsov, "How import integration changes firms' decisions to innovate," Ann. Reg. Sci., vol. 60, no. 3, pp. 501528, 2018.

[52] L. Yu, H. Li, Z. Wang, and Y. Duan, "Technology imports and selfinnovation in the context of innovation quality," Int. J. Prod. Econ., vol. 214, pp. 44-52, 2019.

[53] M. Bombardini, G. Orefice, and M. D. Tito, "Does exporting improve matching? Evidence from French employer-employee data," J. Int. Econ., vol. 117, pp. 229-241, 2019.

[54] L. Brandt, J. Van Biesebroeck, L. Wang, and Y. Zhang, "WTO accession and performance of Chinese manufacturing firms," $\mathrm{Am}$. Econ. Rev., vol. 107, no. 9, pp. 2784-2820, 2017.

[55] P. Bustos, "Trade liberalization, exports, and technology upgrading: Evidence on the impact of MERCOSUR on Argentinian firms," Am. Econ. Rev., vol. 101, no. 1, pp. 304-340, 2011.

[56] P. Aghion, A. Bergeaud, M. Lequien, and M. J. Melitz, "The impact of exports on innovation: Theory and evidence," 2018

[57] E. A. Bøler, A. Moxnes, and K. H. Ulltveit-Moe, "R\&D, international sourcing, and the joint impact on firm performance," Am. Econ. Rev., vol. 105 , no. 12 , pp. 3704-3739, 2015.

[58] K. Wang and W. Tao, "Exploring the complementarity between product exports and foreign technology imports for innovation in emerging economic firms," Eur. J. Mark., vol. 53, no. 2, pp. 224-256, 2019.

[59] F. Pieri, M. Vecchi, and F. Venturini, "Modelling the joint impact of R\&D and ICT on productivity: A frontier analysis approach," Res. Policy, vol. 47, no. 9, pp. 1842-1852, 2018.

[60] J. Jeon, S. Kim, and J. Koh, "Historical review on the patterns of open innovation at the national level : the case of the roman period," J. Open Innov. Technol. Mark. Complex., pp. 1-17, 2015.

[61] Y. Kim, D. A. Briley, and M. G. Ocepek, "Computers in Human Behavior Differential innovation of smartphone and application use by sociodemographics and personality," Comput. Human Behav., vol. 44, pp. 141-147, 2015

[62] F. Venturini, "The modern drivers of productivity," Res. Policy, vol. 44, no. 2, pp. 357-369, 2015.

[63] C. Corrado, J. Haskel, and C. Jona-Lasinio, "Knowledge spillovers, ICT and productivity growth," Oxf. Bull. Econ. Stat., vol. 79, no. 4, pp. 592-618, 2017.

[64] X. Fu, P. Mohnen, and G. Zanello, "Innovation and productivity in formal and informal firms in Ghana," Technol. Forecast. Soc. Change, vol. 131,2018

[65] A. C. Fieler, M. Eslava, and D. Y. Xu, "Trade, quality upgrading, and input linkages: Theory and evidence from colombia," Am. Econ. Rev., vol. 108, no. 1, pp. 109-146, 2018.

[66] L. Edwards, M. Sanfilippo, and A. Sundaram, "Importing and firm performance: new evidence from South Africa," WIDER Working Paper, 2016.

[67] L. E. Okafor, M. Bhattacharya, and H. Bloch, "Imported intermediates, absorptive capacity and productivity: evidence from Ghanaian manufacturing firms," World Econ., vol. 40, no. 2, pp. 369392, 2017.

[68] N. Foster-mcgregor and R. Stehrer, "Value added content of trade : A comprehensive approach," Econ. Lett., vol. 120, no. 2, pp. 354-357, 2013.

[69] B. Crépon, E. Duguet, and J. Mairessec, "Research, Innovation And Productivi [Ty: An Econometric Analysis At The Firm Level," Econ. Innov. new Technol., vol. 7, no. 2, pp. 115-158, 1998.

[70] H. Lööf, J. Mairesse, and P. Mohnen, "CDM 20 years after." Taylor \& Francis, 2017.

[71] J. Guan and R. C. M. Yam, "Effects of government financial incentives on firms' innovation performance in China: Evidences from Beijing in the 1990s," Res. Policy, vol. 44, no. 1, pp. 273-282, 2015.

[72] Y. Zhang, U. Khan, S. Lee, and M. Salik, "The Influence of Management Innovation and Technological Innovation on Organization Performance. A Mediating Role of Sustainability," 
Sustainability, vol. 11, no. 2, p. 495, 2019.

[73] G. Teplykh, "Analysis of the Innovation Activities of Firms Using the CDM Approach,” Probl. Econ. Transit., vol. 58, no. 5, pp. 443-462, 2016.

[74] D. M. Reid, "Absorptive capacity and innovation in China," Int. J. Emerg. Mark., vol. 14, no. 1, pp. 134-154, 2019.

[75] J. Masso and P. Vahter, "Innovation and Firm Performance in a Catching-up Economy," Proc. from Conf. Micro Evid. Innov. Dev., no. 6853, pp. 1-23, 2007

[76] B. Yuan and Q. Xiang, "Environmental regulation, industrial innovation and green development of Chinese manufacturing: Based on an extended CDM model," J. Clean. Prod., vol. 176, pp. 895-908, 2018.

[77] C. Curran and J. Leker, "Technological Forecasting \& Social Change Patent indicators for monitoring convergence - examples from NFF and ICT," Technol. Forecast. Soc. Chang., vol. 78, no. 2, pp. 256273, 2011.

[78] L. Barasa, P. Vermeulen, J. Knoben, B. Kinyanjui, and P. Kimuyu, "Innovation inputs and efficiency: manufacturing firms in SubSaharan Africa," Eur. J. Innov. Manag., vol. 22, no. 1, pp. 59-83, 2019.

[79] X. Fu, C. Pietrobelli, and L. Soete, "The role of foreign technology and indigenous innovation in the emerging economies: technological change and catching-up," World Dev., vol. 39, no. 7, pp. 1204-1212, 2011 .

[80] S. Biggs, "Participatory technology development: a critique of the new orthodoxy," AVOCADO Ser., vol. 6, no. 95, pp. 1-10, 1995.

[81] M. Ghosh and R. P. Roy, "FDI, Technology Imports and R\&D in Indian Manufacturing: Revisited," in Globalisation of Technology, Springer, 2018, pp. 127-149.

[82] M. Kim, "Does Import Competition Reduce Domestic Innovation? Evidence from the'China Stock'and Firm-Level Data on Canadian Manufacturing," Centre for the Study of Living Standards, 2019.

[83] Q. Liu and L. D. Qiu, "Intermediate input imports and innovations Evidence from Chinese firms' patent filings," J. Int. Econ., vol. 103, pp. 166-183, 2016

[84] B. Shepherd, "Openness and Innovation: Firm-level Evidence from India," South Asia Econ. J., vol. 18, no. 1, pp. 64-75, 2017.

[85] Y. A. Abubakar, C. Hand, D. Smallbone, and G. Saridakis, "What specific modes of internationalization influence SME innovation in Sub-Saharan least developed countries (LDCs)?," Technovation, vol. 79, no. May 2016, pp. 56-70, 2019.

[86] K. Lee and F. Malerba, "Catch-up cycles and changes in industrial leadership: Windows of opportunity and responses of firms and countries in the evolution of sectoral systems," Res. Policy, vol. 46, no. 2, pp. 338-351, 2017

[87] T. Farole and D. Winkler, "Firm location and the determinants of exporting in low-and middle-income countries," J. Econ. Geogr., vol 14, no. 2, pp. 395-420, 2014.

[88] H. Evanschitzky, M. Eisend, R. J. Calantone, and Y. Jiang, "Success factors of product innovation: An updated meta-analysis," J. Prod. Innov. Manag., vol. 29, pp. 21-37, 2012.

[89] C. Altomonte, T. Aquilante, G. Békés, and G. I. P. Ottaviano, "Internationalization and innovation of firms: evidence and policy," Econ. policy, vol. 28, no. 76, pp. 663-700, 2013.

[90] P. Almodóvar, J. Saiz-Briones, and B. S. Silverman, "Learning through foreign market participation: the relative benefits of exporting, importing, and foreign direct investment," J. Technol. Transf., vol. 39, no. 6, pp. 915-944, 2014.

Authors:

Benjamin Azembila Asunka, Master of Business Administration. He is currently a lecturer in the School of Business and Management of the Bolgatanga Polytechnic and a $\mathrm{PhD}$ candidate in the School of Management, Jiangsu University of China. His research interests include Innovation Management, Entrepreneurship, Strategic Management and Corporate Governance. He has been engaged in working on some projects of the Jiangsu Province along with his professors in the Jiangsu University.

Zhiqiang Ma, PhD. Professor at the School of Management, Jiangsu University of China. His research interests include Management Science and Engineering as well as Business Administration. He has won the prize of the advanced individual of Jiangsu postdoctoral management, the advanced individual of Jiangsu subject construction management and the school excellent educator prize. He has long been engaged in the teaching research work of management. He has worked on 7 important project of Jiangsu Social science fund among others. He has won 4 prizes of city department director level and above and published more than 40 papers and 2 books.

Mingxing $\mathrm{Li}, \mathrm{PhD}$. Professor at the School of Management, Jiangsu University of China. His research interests include innovation management and Intellectual Property Rights. He has worked on projects including the Soft science project of the State Intellectual Property Office, patent pool construction and operational mode of the strategic emerging industries - A Case Study of Jiangsu Province (SS12A-08) and the Zhenjiang City Soft Science Project, Zhenjiang Intellectual Property Strategy Outline (RK2009010).

Oswin Aganda Anaba, Master of Business Administration. He is currently a lecturer in the Department of Liberal Studies of the Bolgatanga Polytechnic and a $\mathrm{PhD}$ candidate in the School of Management, Jiangsu University of China. His research interests include SME Development, Innovation Management, Entrepreneurship and Strategic Management. He has been engaged in working on some projects of the Jiangsu Province along with his professors in the Jiangsu University. 